\title{
The unevenly absorbed and induced intra-regional Facebook adoption in Western Ukraine
}

\author{
Serhii Puhach ${ }^{1, *}$, Kostyantyn Mezentsev²
}

\footnotetext{
${ }^{1}$ Lesia Ukrainka Volyn National University, Faculty of Geography, Department of Economic and Social Geography, Ukraine

${ }^{2}$ Taras Shevchenko National University of Kyiv, Faculty of Geography, Department of Economic and Social Geography, Ukraine

* Corresponding author: puhachserhiy@gmail.com
}

\begin{abstract}
This paper aims to reveal and explain the spatial pattern of Facebook adoption in Western Ukraine. It discusses how to trace the fragmented nature of social networking services' (SNS) penetration at the intra-regional level using Facebook data analysis. This study has confirmed the expectation that in Western Ukraine Facebook adoption is predominantly an urban phenomenon, but with some peculiarities depending on the local context. The largest cities and regional centers attract the highest number of users, while peripheral and the economically least developed places have the lowest Facebook penetration rate. However, there are some areas with a higher number of Facebook adopters caused by a specific rural settlement system and the location in the Carpathians with no large cities 'pulling' the audience. The spatial pattern of Facebook adoption in Western Ukraine is an intricate and intertwined mosaic of 'SNS hubs' and peripheries, suggesting a 'digital differentiation' rather than a 'digital divide'.
\end{abstract}

\section{KEYWORDS}

social networking service (SNS); Facebook; Facebook adoption; penetration rate; spatial pattern; Western Ukraine

Received: 2 October 2020

Accepted: 18 May 2021

Published online: 26 July 2021

Puhach, S., Mezentsev, K. (2021): The unevenly absorbed and induced intra-regional Facebook adoption in Western Ukraine. AUC Geographica 56(2), 157-167 https://doi.org/10.14712/23361980.2021.10

(C) 2021 The Authors. This is an open-access article distributed under the terms of the Creative Commons Attribution License (http://creativecommons.org/licenses/by/4.0). 


\section{Introduction}

In recent years, the fast development of technologies has brought a range of new opportunities and at the same time disappointments to different people and communities. Connectivity and accessibility have grown significantly and one can travel longer distances faster than ever before. However, in many cases, travelling has become less necessary due to the virtual communication. Social networking services facilitated contacts between spatially remote and culturally distinctive areas. Use of social networking services such as Facebook, Twitter, Instagram, Telegram, TikTok, etc. has become commonplace in everyday life for different aims - communication, business, entertainment, obtaining information, etc. The integrating of social networking services and mobile phones with the Global Positioning System (GPS) allows users to facilitate the search for people and things in the real (physical) world, to localize the content they create. Social networking services contain spatial data on the location of users and their links with friends.

Moores (2012) emphasizes that some existing approaches have mistakenly associated SNS use with placelessness (Moores 2012). The ways in which people adopt and use Facebook reflect their cultural norms and practices (Hong and Na 2018). 'Absorbing' entire countries and regions, Facebook becomes a global cultural trait. But within individual regions, its adoption is uneven and caused by various factors. Moreover, in some countries Facebook 'meets' with considerable influence of the regional SNS. Thus, the population of Ukraine was at the 'frontline' of influence and intersection of global and post-Soviet (Russian-produced) SNS. But Russian aggression and further sanctions towards Russian SNS companies in Ukraine led to the prioritizing Facebook and inducing its penetration. That is, the global trend of 'absorption' of Ukraine's regions by Facebook was accelerated by the ban on Russian SNSs (VKontakte, Odnoklassniki) from May 2017 in accordance with the Presidential Decree "On the Implementation of Personal Special Economic and Other Restrictive Measures (Sanctions)" (President Ukraine 2017) widely known as the "Decree on the ban of Russian sites and social networks." Just before the Russian aggression, the number of Ukrainian Facebook users was only 3.2 million (Yandex 2014), and after it increased to 8.3 million (PlusOne 2019). Thus, to some extent, Facebook has become a symbol of pro-European and VKontakte of pro-Russian orientation. As a result, Facebook gained new users more easily and quickly in the least Russian-oriented Western Ukraine (StatCounter 2021). However, the rate of Facebook penetration into the region varies significantly at the level of administrative districts (rayons) and settlements.

In Ukraine, social networking services are studied mostly by sociologists with focuses on the impact on society, age effects (first of all children and adolescents), use of the SNS in political technologies, education and training. In some cases, the media publish reviews on various quantitative technical characteristics of the SNS performed by IT specialists. Such studies mostly do not consider the spatial aspects or cover them superficially.

In geographical studies, SNS rather are not considered properly. There are some geographical aspects in the surveys "Review of Social Networking Services and Twitter in Ukraine ..." (Yandex 2014), "Facebook and Instagram in Ukraine (September 2019)" (PlusOne 2019). Also, there are some investigations of the spatial features of SNS use under the armed conflict in Eastern Ukraine (Dobysh 2019), the distribution of social networking services in Ukraine (Puhach and Mytchuk 2017) and some regions (Puhach and Mytchuk 2018; Puhach and Maister 2020; Puhach at al. 2020). However, there are no detailed studies of the SNS adoption among the population at the intra-regional and local levels.

While the topic of Facebook geographies is not new, studies of place-based Facebook adoption in Ukraine, especially at the intra-regional level, are overlooked. This research is aimed at overcoming this shortcoming. Therefore, the paper aims to illuminate the spatial pattern of Facebook adoption in Western Ukraine. The main research questions are following. How to trace the fragmentation of Facebook penetration at the intra-regional level using Facebook data analysis? What are the main drivers of Facebook adoption in Western Ukraine?

\section{Stepping to Facebook geography}

In the last decades, human geography undergoes changes in terms of expanding the research field. Virtual geography, cyber geography, and Internet geography are on the rise, focusing on the locational dimensions in physical space, relying on the data at numerous geographical scales (cities, regions, countries), and reflecting the rate of adoption and use of the Internet, mobile phones, and other communications media and technologies (Kellerman 2016).

A number of researchers emphasize that social relations are better understood through the networks rather than totals (aggregates) (Castells 1996; Bingham 1999). According to Kellerman (2016), the geography of cyberspace consists of the geographical aspects of websites and communication platforms. Social networks including Facebook are relatively new phenomenon in the field of social relations, realized on the basis of the World Wide Web and mobile telephony. Social communications seemingly have covered the whole world, but with essential disparities and distinctive signs of socio-spatial injustice. 
Geographers study the Internet and virtual spaces from the late 1990s, although these researches were sporadic and even now geographical researches on whether and how the Internet changing the ways in which social relations, social spaces and identities are produced remain quite small in number (Horton and Kraftl 2014). The most of them are based on two key concepts of cyberspace and network society. The first one was coined by the science fiction writer William Gibson in his novel "Neuromancer" (Gibson 1984), but was later widely used by scholars. The second concept was proposed by Castells to designate a new spatial form of society organization (Castells 1996). According to Warf (2013), this was one of the most productive interpretations of the Internet, which prevents technological determinism.

Cyberspace has ceased to be just a word, instead it has been viewed as a full-fledged subject of research, "which is everywhere" (Bingham 1999). Later, along with the cyberspace, the 'virtual space' concept also became widespread. Some researchers identify them as the same, others point to their differences. Subsequently, the "Internet space" also entered into circulation. Kellerman (2016) hierarchically arranges these terms. Virtual space as the widest entity includes various cyber and non-cyber spaces, and cyber space, in turn, include Internet space.

The "explosion of the Internet" stimulated the development of the geographies of cyberspace (Warf 2006a). Kitchin (1998) identified the set of the geographies of cyberspace subdivisions - economic, social, cultural, political geographies of cyberspace. Regarding the geographies of cyberspace, he emphasized that 1) cyberspatial communication challenges both the traditional ideas concerning mass communication and forms of communication; 2) cyberspace interaction blurs modernistic dualisms, such as virtuality with reality and technology with nature; 3 ) cyberspace transforms space-time relations and creates new social spaces that lack the formal qualities of geographic spaces (Kitchin 1998). The third statement is the most important for geographers.

The geography of the Internet (Internet geography, or cybergeography) is distinguished as a separate branch of the geography of communications (Tranos 2013). At the same time, Tranos distinguishes the social geography of the Internet, which is divided into political, cultural and economic geography of the Internet (Ibid.). Virtual geography in a broad view studies the spatial aspects of information and communication technologies, including the Internet and SNS in particular. It reflects a heterogeneous combination of material and symbolic relationships (Crampton 2006).

In this study, we propose to go further and talk about Facebook geography as a part of virtual geography. Facebook can be considered as not only an object of study but also a source (Rogers 2013). We can identify different dimensions of Facebook geography. On the one hand, it focuses on the study of (virtual) Facebook spaces, the formation of virtual social communities, their communication, and mutual perception. On the other hand, it gives the opportunity to look at the real (physical) spaces and places through the lens of Facebook adoption and penetration on different geographical scales (countries, regions, cities). Moreover, Facebook data allows us to study not only 'standard' demographics of users, but also gives a chance to scope the post-demographics in social networking platforms, while the interest has shifted from the traditional demographics of race, ethnicity, age, income, and educational level to tastes, interests, favorites, groups, accepted invitations, installed apps, and other information that comprises an online profile (Rogers 2013). A lot of previously unexplored information about social network users is now available for study. The geographical investigations of SNS push a new approach of 'spatial postdemographics'.

\section{Place-based Facebook adoption and use}

With the 'advent' of Internet (virtual) space, scholars discuss the "death of distance", "the decline of geography" and consider these spaces as 'spaceless' (in terms of the geographic nature of the space), 'placeless', decentralized, equally accessible, and so on. However, a number of researchers (Crampton 2006; Kitchin 1998; Tranos 2013; Warf 2013, etc.) have proven that Internet spaces have a "distinct geography" (Crampton 2006), and the Internet is characterized by spatiality (Tranos 2013). As Warf (2013) notes, the realities of adoption and using the Internet are in the fact that it is closely interconnected with the regional, national and local political systems, economy and culture, and Facebook geography is caused by the spatiality of the world socio-economic systems. Moreover, they can be both a result and a cause of uneven socio-economic development, 'digital divide' and 'digital inequality'. At the same time, studies of the Internet use tend to show that technology does not always radically change the way people communicate (Horton and Kraftl 2014).

Boellstorff (2016) emphasizes false opposition between the virtual (digital, online) and real. And a new era in the Internet research no longer concerns itself with the divide between the real and the virtual (Rogers 2013). Moores (2017) asserts that we do not live in a placeless culture or in anything close to it, and physical settings are now augmented by a digital network of information that is organized according to the user's location. Facebook is not a separate specific (virtual) world, but has already been embedded deeply in daily lives of the users (Hong and $\mathrm{Na} 2018$ ). 
The current stage of the Internet development with the advent of IP-to-geo technology some scholars consider as the "revenge of geography" on cyberspace, and even more dramatic formulation of the "death of cyberspace", "the end of the virtual" (Rogers 2013; Miller and Slater 2000). Facebook now routinely knows a user's geographical location, and acts upon the knowledge, increasingly became less placeless, if it ever was (Rogers 2013). Facebook is actively involved in place-making practice by creating a "density of meaning" for places in both the virtual and real worlds (Moores 2012, 2017). Different companies and institutions create accounts in Facebook to promote their goods, services, and activities primarily in the certain spatial unit of the real (physical) world. The same way, individuals through their personal accounts represent themselves. Jordaan and Heerden (2017) findings highlight the fact that Facebook is a part of users' lives and daily routine, and it contributes to their identity construction, entertainment, and relationship value.

Kitchin (1998) suggests that geography remains the first in the study of cyberspace because cyberspace does not create an alternative world, but exists in a symbiotic relationship with physical space. "Cyberspaces are dependent upon spatial fixity, they are embodied spaces and access is unevenly distributed" (Kitchin 1998: 403). Internet spaces are produced in the socio-political conditions of physical spaces, but, in turn, they simultaneously impact on material geographies (Crampton 2006). In the age when more and more aspects of everyday life are connected with electronic infrastructure, theoretical views have gone beyond the simplified dichotomy of 'online' and 'offline', physical and virtual are increasingly influencing each other (Warf 2006b). For instance, Tóth et al. (2021) demonstrate that urban topology (significant distances, physical barriers, or spatially concentrated amenities) is related to social network fragmentation and latter in turn compounds income inequality over time.

Spread of the SNS is a driver of the both increasing opportunities and spatial inequalities. In some countries it contributes to expanding opportunities for more vulnerable (marginalized) social groups and economic growth, while in others it strengthens existing "hierarchies of the wealth and power", causing significant "information asymmetries" (Warf 2013). New technology produces inequalities while not everybody can afford new technological devices (Paasi 2003).

The idea of 'digital divide' suggests that a high level of Internet access is more typical for higher-income societies, and vice versa, a low level is a feature of the lower-income societies. Economic development prompts access to the network, and access to the network propels economic development (Adams 2006). Although the 'digital divide' remains, it is gradually changing between and within countries, manifesting at different spatial scales (Warf 2013, 2017). Moreover, the 'digital divide' in different countries differs markedly in the degree of manifestation, causes and results (Warf 2013: 40). The concepts of accessibility and use of the Internet are rather ambiguous, in particular in terms of access (e.g., the Internet access at home, school, cafe or work). Therefore, instead of a simple dichotomy of accessibility/inaccessibility, Warf (2017) suggests to think of a "gradation of levels of access" (Warf 2017).

Facebook adoption and use is essentially dependent on local context. A number of studies were aimed to find the main drivers of the spatial distribution of Internet networks. Thus, Warf (2013) concludes that the "uneven spatiality" of the Internet is caused by many factors - differences in income, literacy, demographic structure (especially age structure), gender relations, telecommunications policy, and government censorship. This unevenness creates the geography of cyberspace, which is multi-scale in nature (Warf 2013). Tranos (2013) emphasizes on macroeconomic conditions (especially market size), urbanization and 'world city-ness', location (coastal and border regions) as the significant factors which affect the uneven distribution of Internet infrastructure in Europe.

Wide literature is devoted to the study of spatial distribution and spatial patterns of the SNS users location and interaction (Ter Wal and Boschma 2009; Glückler and Doreian 2016; Menezes and Roth 2017; Borge-Holthoefer et al. 2011; Sui and Goodchild 2011; Andris 2016), and the role of distance in the SNS spread and network users social connections (Bailey et al. 2018; Lengyel et al. 2015; Laniado et al. 2017). Takhteyev et al. (2012) shows the impact of distance, national borders, language and frequency of air travel on the formation of social ties in Twitter. Moreover, administrative boundaries continue to exist in the virtual world of social networking service. Social connectedness recreates the contours of the administrative-territorial division, and virtual connections are mostly a duplication of communications in the real (physical) world (Bailey et al. 2018).

\section{Data and methodology}

The geography of the virtual spaces is 'a vague concept', thus lacking clear and systematic methodologies for its analysis and interpretation (Kellerman 2016). The SNS can be analyzed in terms of their spatial extent, degree of connectivity, directorial bias, and regional concentration (Pitzl 2004). Moreover, individual SNS such as Facebook can be a powerful research tool to investigate how the ways in which people perceive and use it reflect their cultural norms and practices (Hong and $\mathrm{Na} 2018$ ), and to understand its penetration at different spatial scales. 
An empirical research of the SNS is challenged by the unavailability of extensive and representative data on the users of different social networking services by certain age, social groups or territorial units. Some recent spatial studies addressed the social networking services as Facebook, LinkedIn, Twitter or Instagram are based on anonymous data from the SNS. Usually these data obtained through collaboration with teams that include, for instance, Facebook employees. However, there is a certain limit to the number of researchers who will be able to work with the data from social media through such collaboration. Such circumstances determine demand for a new approach to study social networking services that will allow collecting data by anyone independently from the social media managements decisions.

There are some difficulties with the collection of primary data regarding SNS users. First, user accounts are personal information that company is not entitled to disclose without the owner consent. Remember the recent Facebook-related scandals on the use of personal data in the political technologies during the US presidential election and Brexit (BBC 2018; Sanders and Patterson 2019; Wong and Morris 2018). Second, SNSs are transformed into large-scale corporate-controlled financial and business projects with revenues related to the size of the network. Since, services often overestimate the number of their own users. Third, the same user can have multiple accounts, some of them of little or none use for some reason. Fourth, many bots, i.e. special programs that carry out certain actions through an interface designed for users, are hidden under some SNS accounts. Based on the above, we can talk only about the estimated number of SNS users.

Our research methodology is not something completely new. There are many works on social media marketing (SMM) and applied methods of their use (e.g. AdEspresso 2020). It based on the open data estimated by Facebook and presented under the category "People who live in this location", where location is set by the location on Facebook users' profiles and confirmed by their IP address. In doing so, we focused on assessing the extent of Facebook adoption, but without analyzing the connectivity of individual users and locations, because the data used do not have a network structure.

To assess the number of Facebook users, we have used the targeting tool, an advertising mechanism that allows picking out from the total Internet audience only the portion of visitors or target audience that fits certain criteria (Facebook 2020). The main criterion is the territorial coverage (AdEspresso 2020). To do this, we followed "Advertising - Create an Ad - Reach - Set Up Ad Account" at the Facebook page. In the Placements section "Edit Placements" was selected. Only "Facebook" was chosen among "Platforms." In the Audience section, we set the parameters
"People who live in this location", "Age" from 13 to $65+$, and "Gender" - "All". In the map window ("Locations"), the territorial units were allocated by their names. For districts (rayons) we used the search by postal codes (Postal codes of Ukraine 2020). In cases when service provides unreliable data (e.g., the number of users less than 1000), the "Drop Pin" tool was used - the district area was 'covered' with circles of different radius.

The data were collected for all local territorial units (rayons) of seven Western Ukrainian regions - Volyn, Zakarpattia, Ivano-Frankivsk, Lviv, Rivne, Ternopil, Chernivtsi. These Ukraine's regions later than others became a part of the USSR, characterised by some common culture traits, vigorous pro-European sentiments, and closer links with the EU countries.

Data on the number of SNS users in Western Ukraine was collected in the late January 2020. In addition to the total number of users, we suggest to use Facebook penetration rate $\left(P_{s n s_{i}}\right.$, in \%):

Psns $_{i}=\left(N_{i} / P_{i}\right) \times 100 \%$,

where $N_{i}$ - the number of Facebook users in district $i$ (thousand people); $P_{i}$ - total population of the district $i$ (thousand people). The data on population size (as of October 1, 2019) was collected from the official web-sites of the regional departments of the State Statistics Service of Ukraine (2020).

\section{Facebook adoption in Western Ukraine: large cities matter}

Facebook is one of the largest segments of the Internet with total number of users exceeding 2.7 billion people (Zephoria 2020) and the most popular social networking services in Ukraine (Research \& Branding Group 2020). Its average monthly audience in Ukraine is 14.0 million users (Facebook 2020), i.e. it covers one third $(33.4 \%)$ of the country's population (as of early 2020). There are $3.45 \mathrm{mln}$ Facebook users in Western Ukraine, or $37.3 \%$ of the region's population, and $24.7 \%$ of all Ukrainian network users. The share of Western Ukraine in the country's population is $22.1 \%$, that is, Facebook penetration rate in the region is higher than average in Ukraine. This is in line with our previous researches which found an increasing Facebook penetration rate in Ukraine from east to west.

The number of users is relatively proportional to the population size at the district level (districts and cities of regional subordination), as evidenced by statistically significant Spearman's $r=0.43$ with the $p$-value less than 0.05 (while Pearson's $r=0.94$, $\mathrm{p}<0.01$ ). At the regional level, the largest number of users is in Lviv (1.0 mln), Ivano-Frankivsk $(0.5 \mathrm{mln})$, Zakarpattia $(0.49 \mathrm{mln})$ regions, and the least is in Chernivtsi region $(0.3 \mathrm{mln})$ (Table 1$)$. 
Tab. 1 Western Ukraine: Population, urbanization, Facebook users and penetration (2020).

\begin{tabular}{|c|c|c|c|c|c|c|c|c|}
\hline & \multicolumn{7}{|c|}{ Regions } & \multirow{2}{*}{ 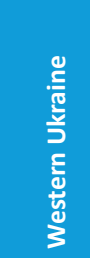 } \\
\hline & $\frac{5}{0}$ & 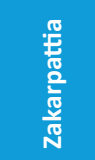 & 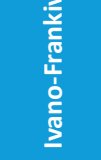 & 主 & 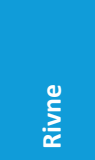 & 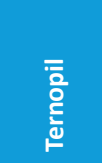 & 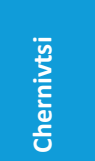 & \\
\hline \multicolumn{9}{|l|}{ Population } \\
\hline size (1,000 people) & 1032.2 & 1254.3 & 1368.8 & 2513.8 & 1153.7 & 1039.7 & 901.9 & 9264.4 \\
\hline share in Ukraine (\%) & 2.5 & 3.0 & 3.3 & 6.0 & 2.8 & 2.5 & 2.2 & 22.1 \\
\hline Urbanization (\%) & 52.2 & 37.1 & 44.2 & 61.0 & 47.5 & 45.3 & 43.2 & 49.1 \\
\hline \multicolumn{9}{|l|}{ Facebook users } \\
\hline number ( 1,000 people) & 363.9 & 488.0 & 517.4 & 1038.8 & 376.8 & 374.7 & 294.0 & 345.3 \\
\hline share in Ukraine (\%) & 2.6 & 3.5 & 3.7 & 7.4 & 2.7 & 2.7 & 2.1 & 24.7 \\
\hline $\begin{array}{l}\text { share of regional center in the } \\
\text { region's audience (\%) }\end{array}$ & 49.5 & 20.5 & 38.7 & 62.6 & 58.4 & 50.7 & 81.6 & 18.8 \\
\hline $\begin{array}{l}\text { share of cities of regional } \\
\text { subordination in the } \\
\text { region's audience (\%) }\end{array}$ & 75.6 & 40.8 & 59.5 & 81.7 & 71.4 & 65.4 & 84.3 & 69.4 \\
\hline \multicolumn{9}{|l|}{ Penetration rate (\%) } \\
\hline region & 35.3 & 38.9 & 37.8 & 41.3 & 32.7 & 36.0 & 32.6 & 37.3 \\
\hline regional center & 82.9 & 86.9 & 76.1 & 86.0 & 89.4 & 85.2 & 90.0 & 85.2 \\
\hline second city & 76.1 & 80.4 & 59.0 & 55.2 & 35.5 & 101.2 & 74.2 & 90.0 \\
\hline third city & 35.9 & 50.6 & 66.9 & 48.9 & 72.0 & 57.6 & - & 76.1 \\
\hline fourth city & 59.9 & 58.5 & 66.9 & 65.3 & 45.9 & 73.8 & - & 89.4 \\
\hline cities of regional subordination & 63.7 & 65.7 & 57.7 & 57.8 & 60.7 & 79.4 & 82.1 & 64.0 \\
\hline districts & 13.5 & 25.9 & 23.8 & 14.9 & 12.3 & 18.6 & 7.1 & 16.7 \\
\hline
\end{tabular}

Source: Authors' calculations using data (Facebook 2020; State Statistical Services of Ukraine 2020).

One can see a distinct trend towards the concentration of most accounts registration in the largest cities. Thus, the main regional and sub-regional centers (cities with the status of regional subordination) in Western Ukraine cover $69.4 \%$ of the users. Among regions, this indicator varies from $40.8 \%$ in Zakarpattia region to $84.3 \%$ in Chernivtsi region (Table 1 ). The most of accounts are registered in the regional centers Lviv (0.65 mln), Chernivtsi, Rivne, Ivano-Frankivsk (more than $0.2 \mathrm{mln}$ ), and Ternopil, Lutsk, Uzhhorod (more than $0.1 \mathrm{mln}$ ) (Figure 1). The largest city of Lviv covers $18.8 \%$ of Facebook audience in Western Ukraine. Regional centers cover from 20.5\% (Zakarpattia region) to $81.6 \%$ (Chernivtsi region) users of the respective regions. This is to some extent related with the settlement pattern and concentration of socio-economic activity. So, social networking services are mainly an urban phenomenon, which is gradually spreading its influence on the suburbia and further to rural areas. This is in line with Warf (2017) conclusion on the significant predominance of the Internet development in large cities.

In terms of audience size, other cities are far behind the regional centers. Yet among them there are also some 'sub-leaders' as Mukachevo, Drohobych, Kovel, Kolomyia (more than 40 thsd. of users). These are powerful socio-economic centers of a subregional level, the 'focuses of life' for neighboring districts.

The number of Facebook users by districts varies significantly, and in general it is proportional to the population number. However, there is essentially lower number of accounts in the districts adjacent to the cities of regional subordination. This is especially evident for Lviv, the largest city in Western Ukraine, and to a lesser extent for Chernivtsi and Ternopil (Figure 1). One of explanation is that the data on Facebook users in large cities includes suburban ones. It is especially notable in the case of Lviv and Chernivtsi, where neighboring rural settlements are served by the city's Internet providers. Also, suburban users who are working in the main cities get access to the Internet via corporate networks, or wi-fi in trade and entertainment centers, and other public networks. That is, Facebook algorithms fix this set of mobility as the same settlement. This explains somewhat inflated number of users in the large cities and the smaller number in suburban districts.

Against the background of distinct leading centres, one can see some areas with higher number of Facebook users (with audience over 20 thsd.) in Zakarpattia (Tyachiv, Vynohradiv, Irshava, Rakhiv, Khust districts), Ivano-Frankivsk (Nadvirna, Kosiv, Rozhniativ, 


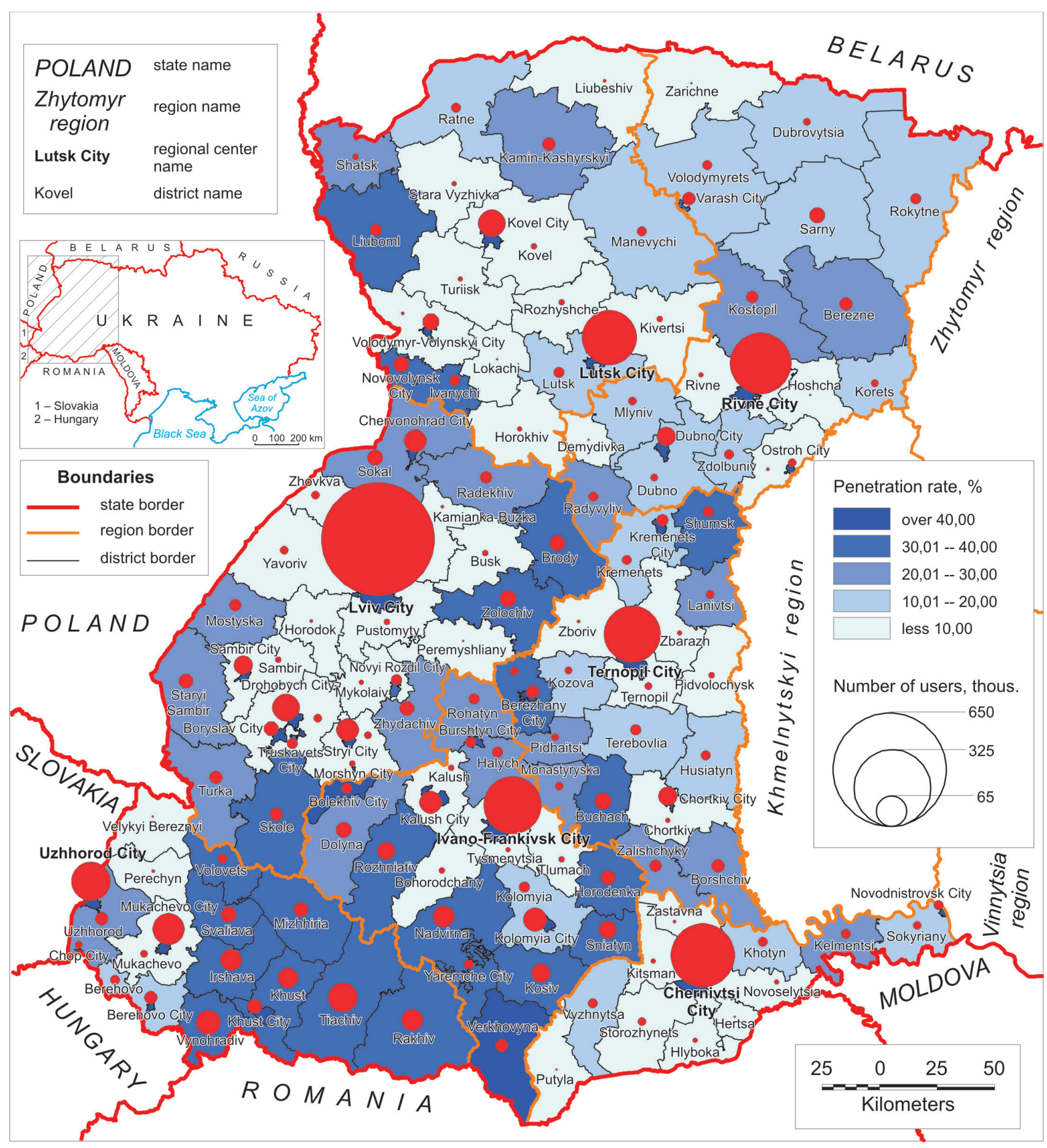

Fig. 1 Facebook adoption in Western Ukraine.

Sniatyn districts), Lviv (Zolochiv district), and Ternopil (Buchach district) regions. It caused by the specific rural settlements system, "pulling effect" of the large cities, and location in the Carpathians, as well.

On the contrary, the districts with the largest population size in Western Ukraine adjacent to the main socio-economic centres have a far smaller audience (Yavoriv, Pustomyty, Zhovkva districts in Lviv region, Mukachevo district in Zakarpattia region, Kalush, Kolomyia districts in Ivano-Frankivsk region, Sarny, Rivne districts in Rivne region, and Storozhynets district in Chernivtsi region) (Figure 1). These districts have a polarized structure comprising areas with growing population in the settlements immediately adjacent to the main centres and identified by Facebook tools as a part of the city, and distinct shrinking areas.

The districts with the lowest number of Facebook adopters (with less than two thousand users) can be divided into two groups: 1) districts adjacent to the cities of regional subordination, and 2) areas with a low population number and peripheral 
disadvantageous location. The backward 'Facebook periphery' consists of a set of rural settlements with no wired Internet, and with the signal of mobile networks which does not allow convenient use of social networks. Urbanization rate in Western Ukraine is relatively low (49.1\%). In many rural settlements, especially in the peripheral parts of the regions, there is no wired Internet, and the signal of mobile networks does not allow convenient use of social networks. That is, the hierarchical character of Facebook adoption is observed.

\section{Uneven Facebook penetration: drivers of the intra-regional fragmentation}

The number of Facebook users is an important indicator to understand spatial variation in SNS adoption among population. However, the penetration rate was used to trace the intra-regional peculiarities and to explain the complicated spatial mosaic of Facebook adopters absorbed by social networking global trend and induced by geopolitical conflict.

In Western Ukraine, the total Facebook penetration rate is of $37.3 \%$, which is slightly higher than the average in Ukraine (33.4\%). This is expected, given the more pro-European orientation of the region's population with a much weaker nostalgia for the Soviet past and an attachment to post-Soviet social networking. After the ban on Russian SNS in 2017 (President of Ukraine 2017), the population of Western Ukraine quickly switched to the global SNSs, first of all Facebook.

Facebook penetration in Ukraine is characterized by two features. First, the penetration rate is increasing from the east to the west. Second, the higher level of socio-economic development, the higher penetration rate (Puhach and Mytchuk 2017). The same pattern can be traced in the case of Western Ukraine at the regional level. The lowest penetration rate of SNS was recorded in the eastern part (in Chernivtsi and Rivne regions with $32.6 \%$ and $32.7 \%$ respectively), and the highest one in the western part (in Lviv and Zakarpattia regions with $41.3 \%$ and $38.9 \%$ respectively). At the same time, the most developed Lviv region has the highest level of Facebook penetration. The relatively high penetration rate $(37.8 \%)$ is observed in next developed (Ivano-Frankivsk) region (Table 1). The high Facebook penetration rate in Zakarpattia region can be additionally explained by intensive communications with neighboring states (Hungary, Slovakia and Romania), first of all because of the family ties and labour migration. Cross-border communication via social networking services is free and therefore an alternative to mobile phone communication.

Facebook penetration rate at first sight is weakly associated with population size. That is, the large population number is a prerequisite but not the main driver of the social networks penetration. The more essential are socio-economic factors and settlement pattern. However, the demographics impact should not be completely ignored. To a large extent, impact of infrastructural underpinnings, in particular broadband Internet and mobile penetration in the region is associated with settlement pattern and economic development with higher access in cities and more developed districts (Dubov and Ozhevan 2013; Kvitka and Mazur 2019).

Facebook penetration in Western Ukraine at the intra-regional level is more fragmented. The main areas with the highest penetration rate are the large cities, but also some districts and towns. The penetration rate in the regional centres is on average $85.2 \%$ with the highest values in Chernivtsi (90.0\%) and Rivne (89.4\%) (Table 1). This can be explained by the settlement system morphology and the presence (or absence) of other centers in the region. Thus, in Chernivtsi region there are no other significant economic centers except Chernivtsi. Vice versa, the relatively lower penetration rate in Ivano-Frankivsk is due to sub-regional centers of Kalush and Kolomyia.

Moreover, the highest penetration rate of Facebook in Western Ukraine is not in the regional center, but in the town of Chortkiv, where Facebook audience is more than population number $(101.2 \%)$. This is likely due to the fact that Chortkiv includes Facebook users of the surrounding villages, as well as the urban village of Zavodske.

Among other cities, a rival of the regional centre Mukachevo, a relatively fast growing second-order city Sambir and a national-wide transport hub Kovel are characterized by the highest level of Facebook penetration (more than 75\%) and higher socio-economic activity as well.

The lowest Facebook penetration rate (less than $36 \%$ ) is recorded in the mining centers Novovolynsk and Novyi Rozdil, a nuclear power station site Varash, and tourist centres Yaremche and Truskavets. It can be explained by their weak connections with the surrounding rural area and some disadvantages caused by their non-administrative centres status.

The penetration rate of the second most populated cities in Western Ukraine regions is averages 68.8\% and varies from $35.5 \%$ (Varash in Rivne region) to $101.2 \%$ (Chortkiv in Ternopil region). The penetration rate of the third most populated city is on average $55.3 \%$ and ranges from $35.9 \%$ (Novovolynsk in Volyn region) to $72.0 \%$ (Dubno in Rivne region). And Facebook penetration rate of the fourth most populated city is on average $61.7 \%$ and varies from $45.9 \%$ (Ostroh in Rivne region) to $73.8 \%$ (Berezhany in Ternopil region) (Table 1).

Thus, the size of the city is not the main driver of Facebook penetration. Interestingly, the fourth cities in Western Ukraine regions have a higher penetration 
rate than the third ones. This indicates transformation processes in the economy and the settlement pattern.

The ranking of second-order administrative-territorial units (districts and cities of regional subordination) by Facebook penetration rate shows that the cities of regional subordination are located at the top of the rating. They have 1-28, 30, 35, 37-39, 41 rank positions. Even the lowest in the ranking Truskavets $(34.9 \%, 41$ st position) is much higher than the median value (there are 141 administrative-territorial units of the second rank in Western Ukraine).

The penetration rate of the social networking service in (mostly rural) districts is much lower than in cities, averaging only $16.7 \%$ (Table 1 ). The highest level is in Zakarpattia (25.9\%) and Ivano-Frankivsk $(23.8 \%)$ regions with dense networks of rural settlements. The majority of districts with higher penetration rate (over $30 \%$ ) are located in the same regions. The cities of Chernivtsi and Rivne have a strong dominance in their regions, so there is no district with a high penetration rate here.

Interestingly, all districts with a relatively high penetration rate are located in the peripheral parts of the regions, at a distance from and with weaker connections with the regional centres, i.e. they are not in the 'shadow' of the regional centers. Since the targeting advertising mechanism was used to determine the number of users by territorial criteria, these districts have, although not a large, but their own 'SNS market'. The lowest Facebook penetration rate $(5 \%$ and below) can be found mostly in Chernivtsi, Lviv and Rivne regions' districts with a high concentration of users in the regional centers (Figure 1). They can be divided into two groups: 1) districts adjacent to the cities of regional subordination (which users are identified by Facebook as the centres' dwellers), and 2) agricultural, rural districts with a peripheral disadvantageous location and low level of socio-economic development.

The social networking services penetration rate in rural areas is significantly far behind urban settlements. However, in recent years the penetration of the Internet, and 3G and 4G mobile technologies into rural areas is growing (at least in large and medium-sized rural settlements). This could change the spatial pattern of Facebook adoption and penetration in the nearest future.

\section{Limitations}

Findings from this study need to be interpreted with some caution due to biases in Facebook data and specifics of settlement pattern and administrative division in Western Ukraine.

Facebook targeting tool picking out from the total Internet audience only target audience that fits location criteria causes some discrepancy that makes the data on users not directly linkable to population data.
This leads to (artificial) underrepresentation of Facebook penetration rates in sub-urban districts while overrepresentation penetration in central cities. To some extent, this limits intra-regional level analysis and could not be seen as a genuine factor driving Facebook penetration.

The low number of users in the districts adjacent to the cities of regional subordination is explained by the peculiarities of the settlement system in Western Ukraine. Ukraine had an outdated (inherited from the USSR) scheme of administrative-territorial division. City limits have not been revised (changed) for about 40 years. Nowadays, cities have sprawled beyond their official boundaries, and the rural settlements adjacent to the city have turned into mostly residential areas ('dormitories') with small businesses and service and leisure facilities. These districts often do not have their own administrative centres. For example, all institutions and departments of Lutsk district state administration are located in the city of Lutsk. In such areas there are no large cities and sharply predominant rural population. Socio-economic life in these districts is highly polarized. They include the developed part, which is directly adjacent to the city (or to the main highways), and the declining periphery. That is, we assume that large cities are actually much larger than administratively defined, and Facebook's algorithms interpret suburban residents as city's users.

Also, data used in this research do not have a network structure which is an additional limitation with respect to their use for other social network analysis.

\section{Conclusions}

This paper is aimed to better understand a spatial pattern of Facebook adoption among Western Ukraine population and trace which places are becoming 'SNS hubs' and which ones remain impenetrable to social networks.

In order to assess social networking services adoption at the intra-regional level we suggest to use Facebook targeting tool and calculate the penetration rate.

Western Ukraine is a macro-region bordering the EU and supposedly more prone for global SNS penetration and 'escape' from Russia-produced and controlled SNS. Thus, Facebook is deeply embedding in region users' daily lives and contribute to their identity construction (Jordaan and Heerden 2017).

This study confirms our expectation that Facebook adoption is predominantly urban phenomenon in Western Ukraine which indicated by both users concentration and network penetration. The largest cities, regional centers expectedly attract the highest number and cover for about half of Facebook users. The main regional center Lviv is also the main center in terms of SNS users' concentration with almost one fifth of all Facebook users in Western Ukraine. High concentration of users near the state borders is poorly 
traced. This is not in line with Tranos (2013) findings concerning positive effect of border regions. Instead, there are some areas with higher number of Facebook adopters caused by specific rural settlements system and location in the Carpathians with no large cities 'pulling' the audience.

Facebook penetration in Western Ukraine is more complicated and fragmented. In the most of cities it is much higher than in rural districts, but all districts with a relatively high penetration rate are located in the peripheral parts of the regions, at a distance from and with weaker connections with the regional centres. Districts neighbouring regional centrres and cities of regional subordination have a far smaller number of users and a low Facebook penetration rate. Although it should be noted that this is related to specifics of users location identifying procedure, when despite the formal administrative boundaries users from the nearest to regional centres settlements (which in fact are the part of the cities) are considered as cities' users, and the rest of the suburban districts accordingly have low adoption and penetration rate. We suggest that the places with the lowest Facebook penetration rate are periphery in both virtual (in terms of Facebook adoption) and physical (in terms of economic development) spaces.

To summing up, what does the case of Western Ukraine show? Facebook adoption is a result of simultaneous tendencies of places 'absorbing' by global SNS and people's geopolitically caused inducing to reject post-Soviet social networks. However, at the intra-regional level we revealed some specifics, such as a distinct east-west gradient and a number of urban centers of Facebook users concentration. Along with the regional centers, there are some relatively distant areas with a higher level of penetration. The spatial pattern of Facebook adoption in Western Ukraine is an intricate and intertwined mosaic of 'SNS hubs' and periphery, yet 'digital differentiation' rather than 'digital divide’ (Warf 2017).

\section{References}

Adams, P. C. (2006): Cyberspace. In: Warf, B. (ed.). Encyclopedia of Human Geography. London, SAGE Publications, 83-85, https://doi.org/10.4135 /9781412952422.n59.

AdEspresso (2020): The Beginner's Guide to Facebook Audiences and Targeting, https://adespresso.com /guides/facebook-ads-beginner/demographic-targeting (accessed September 23, 2020).

Alexa (2020): The top 500 sites on the web, https://www .alexa.com/topsites (accessed January 12, 2020).

Andris, C. (2016): Integrating social network data into GISystems. International Journal of Geographical Information Science 30(10), 2009-2031, https://doi.org /10.1080/13658816.2016.1153103.

Bailey, M., Cao, R., Kuchler, T., Stroebel, J., Wong, A. (2018): Social Connectedness: Measurement, Determinants, and
Effects. Journal of Economic Perspectives 32(3), 259280, https://doi.org/10.1257/jep.32.3.259.

BBC (2018): Facebook scandal 'hit 87 million users'. April 4, https://www.bbc.com/news/technology-43649018 (accessed September 23, 2020).

Bingham, N. (1999): Unthinkable complexity? Cyberspace otherwise. In: Crang, M., Crang, P., May J. (eds.). Virtual Geographies. Bodies, space and relations. London, Routledge, 244-260.

Boellstorff, T. (2016): For Whom the Ontology Turns Theorizing the Digital Real. Current Anthropology 57(4), 387-407, https://doi.org/10.1086/687362.

Borge-Holthoefer, J., Rivero, A., García, I., Cauhé, E., Ferrer, A., Ferrer, D. et. al. (2011): Structural and dynamical patterns on online social networks: the Spanish may 15th movement as a case study. PloS ONE 6(8), e23883, https://doi.org/10.1371/journal.pone.0023883.

Castells, M. (1996): The Rise of the Network Society. Oxford, Blackwell.

Crampton, J. W. (2006): Virtual Geographies. In: Warf, B. (ed.). Encyclopedia of Human Geography. London, SAGE Publications, 535-536, https://doi.org/10.4135 /9781412952422.n321.

Dobysh, M. (2019): Euromaidan and conflict in Eastern Ukraine in social networking sites: Territorial differences of pro-Russian subscriptions in Ukraine. Hungarian Geographical Bulletin 68(1), 51-64, https://doi.org /10.15201/hungeobull.68.1.4.

Dubov, D., Ozhevan, M. (2013): Broadband Access to the Internet as an Important Prerequisite for Ukraine's Innovative Development. Analytical Report. Kyiv, National Institute for Strategic Studies. (In Ukrainian)

Facebook (2020): https://www.facebook.com (accessed September 23, 2020).

Gibson, W. (1984): Neuromancer. London, Grafton.

Glückler, J., Doreian, P. (2016): Editorial: social network analysis and economic geography - positional, evolutionary and multi-level approaches. Journal of Economic Geography 16(6), 1123-1134, https://doi.org /10.1093/jeg/lbw041.

Hong, S., Na, J. (2018): How Facebook Is Perceived and Used by People Across Cultures: The Implications of Cultural Differences in the Use of Facebook. Social Psychological and Personality Science 9(4), 435-443, https://doi.org $/ 10.1177 / 1948550617711227$.

Horton, J., Kraftl, P. (2014): Cultural Geographies. An Introduction. New York, Routledge, https://doi.org /10.4324/9781315797489.

Jordaan, Y., Heerden, V. G. (2017): Online privacy-related predictors of Facebook usage intensity. Computers in Human Behavior 70, 90-96, https://doi.org/10.1016 /j.chb.2016.12.048.

Kellerman, A. (2016): Image spaces and the geography of Internet screen-space. GeoJournal 81, 503-517, https:// doi.org/10.1007/s10708-015-9639-1.

Kitchin, R. M. (1998): Towards geographies of cyberspace. Progress in Human Geography 22(3), 385-406, https:// doi.org/10.1191/030913298668331585.

Kvitka, S., Mazur, O. (2019): Internet access through mobile devices: world experience and perspectives of development in Ukraine. Public Administartion Aspects 7(9-10), 5-18, https://doi.org/10.15421/151944. (In Ukrainian) 
Laniado, D., Volkovich, Y., Scellato, S., Mascolo, C., Kaltenbrunner, A. (2017): The impact of geographic distance on online social interactions. Information Systems Frontiers 20(6), 1203-1218, http://doi.org /10.1007/s10796-017-9784-9.

Lengyel, B., Varga, A., Ságvári, B., Jakobi, Á., Kertész, J., Lengyel B. (2015): Geographies of an Online Social Network. PLoS ONE 10(9), e0137248, https://doi.org /10.1371/journal.pone.0137248.

Menezes, T., Roth, C. (2017): Natural Scales in Geographical Patterns. Scientific Reports 7, e45823, https://doi.org /10.1038/srep45823.

Miller, D., Slater, D. (2000): The Internet: An Ethnographic Approach, 228p. Oxford, Berg.

Moores, S. (2012): Media, Place and Mobility. New York, Palgrave Macmillan, https://doi.org/10.1007 /978-0-230-36012-9.

Moores, S. (2017): Arguments for a Non-Media-Centric, Non-Representational Approach to Media and Place. In: Adams, P.C., Cupples, J., Glynn, K., Jansson, A., Moores, S. Communications/Media/Geographies. London: Routledge, 132-159.

Paasi, A. (2003): Boundaries in a Globalizing World. In: Anderson, K., Domosh, M., Pile, S., Thrift N. (eds.). Handbook of Cultural Geography. London, SAGE Publications, 462-472, https://doi.org/10.4135 /9781848608252.n33.

Pitzl, G. R. (2004): Network. In: Encyclopedia of Human Geography. London, Greenwood Press, 156-157.

PlusOne (2019): Facebook and Instagram in Ukraine (September 2019), https://plusone.com.ua/fb/Facebook _in_Ukraine_PlusOne.pdf (accessed September 23, 2020).

Postal codes of Ukraine (2020): http://www.uaidx.com /?lang=en (accessed September 23, 2020).

President of Ukraine (2017): Decree of the President of Ukraine No133/2017 “On the Implementation of Personal Special Economic and Other Restrictive Measures (Sanctions)". Official online representation of the President of Ukraine, http://www.president.gov.ua /documents/1332017-21850 (accessed April 4, 2020). (In Ukrainian)

Puhach, S., Maister, A. (2020): Spatial features of the distribution of social network services in Volyn region of Ukraine. Acta Geographica Silesiana 14/2(38), 21-27, http://www.ags.wnoz.us.edu.pl/download /wydawnictwa/ags/tom_38_3.pdf (accessed September 23, 2020).

Puhach, S., Mytchyk, Yu. (2017): Geography of social networking services in Ukraine. In: Barskyi, Yu., Puhach, S. (eds.). Human geographical factors of regional development. Lutsk, 99-101, https://konfgeolutsk.files .wordpress.com/2016/11/zbirnyk_sg_chynnyky.pdf (accessed September 23, 2020). (In Ukrainian)

Puhach, S., Mytchyk, Yu. (2018): Spatial analysis of social networking services in the Volyn region. Economic and social geography 79, 14-21, https:// doi.org/10.17721/2413-7154/2018.79.14-21. (In Ukrainian)

Puhach, S., Pohrebskyi, T., Golub, G. (2020): Spatial peculiarities of social networking services distribution in Rivnenska oblast. Human Geography Journal 28, 43-50, https://doi.org/10.26565/2076-1333-2020-28-05.

Research and Branding Group (2020): Practice of using social networking servises in Ukraine, (in Russian), http://rb.com.ua/blog/praktika-polzovanija-socsetjamiv-ukraine (accessed April 4, 2020).

Rogers, R. (2013): Digital Methods. Cambridge, The MIT Press, https://doi.org/10.7551/mitpress /8718.001.0001.

Sanders, J., Patterson, D. (2019): Facebook data privacy scandal: A cheat sheet. TechRepublic, May 14, https:// www.techrepublic.com/article/facebook-data-privacyscandal-a-cheat-sheet (accessed September 23, 2020).

StatCounter (2021): Social Media Stats in Ukraine. Jan 2014 - Jan 2021, https://gs.statcounter.com/socialmedia-stats/all/ukraine (accessed February 16, 2021).

State Statistics Service of Ukraine (2020): Area Bodies of State Statistics, http://www.ukrstat.gov.ua (accessed January 12, 2020).

Sui, D., Goodchild, M. (2011): The convergence of GIS and social media: challenges for GIScience. International Journal of Geographical Information Science 25(11), 1737-1748, https://doi.org/10.1080/13658816.2011 .604636 .

Takhteyev, Y., Gruzd, A., Wellman B. (2012): Geography of Twitter networks. Social Networks 34(1), 73-81, https://doi.org/10.1016/j.socnet.2011.05.006

Ter Wal, A., Boschma, R. (2009): Applying social network analysis in economic geography: framing some key analytic issues. Annals of Regional Science 43(3), 739-756, https://doi.org/10.1007/s00168-008-0258-3

Tóth, G., Wachs, J., Di Clemente, R., Jakobi, Á, Ságvári, B., Kertész, J., Lengyel, B. (2021): Inequality is rising where social network segregation interacts with urban topology. Nature Communications 12, 1143, https://doi .org/10.1038/s41467-021-21465-0.

Tranos, E. (2013): The Geography of the Internet. Cities, Regions and Internet Infrastructure in Europe (New Horizons in Regional Science Series). Cheltenham, Edward Elgar.

Warf, B. (2006a): Introduction. In: Warf, B. (ed.). Encyclopedia of Human Geography. London, SAGE Publications, XXV-XXVIII.

Warf, B. (2006b): Geography and Identity. In: Warf, B. (ed.). Encyclopedia of Human Geography. London, SAGE Publications, 239-241.

Warf, B. (2013): Global Geographies of the Internet. London, Springer, https://doi.org/10.1007/978-94-007-1245-4.

Warf, B. (2017): Alternative Geographies of Cyberspace. In: Kohl, U. (ed.). The Net and the Nation State. Multidisciplinary Perspectives on Internet Governance. Cambridge, University Press, 147-164, https://doi .org/10.1017/9781316534168.011.

Wong, J., Morris, S. (2018): It's complicated. Facebook's terrible 2018. The Guardian, December 24, https://www .theguardian.com/technology/ng-interactive/2018 /dec/24/facebook-2018-timeline-year-in-review-privacy -scandals (accessed September 23, 2020).

Yandex (2014): Review of Social Networking Services and Twitter in Ukraine according to Yandex Blog Search, 2013-2014, https://cache-man01i.cdn.yandex.net /download.yandex.ru/company/Yandex_on _UkrainianSMM_Summer_2014.pdf (accessed February 10, 2018). (In Ukrainian)

Zephoria (2020): The Top 20 Valuable Facebook Statistics Updated August 2020, https://zephoria.com/ top-15-valuable-facebook-statistics (accessed January 12, 2020). 